\title{
Towards novel photodynamic anticancer agents generating superoxide anion radicals: A cyclometalated Ir(III) complex conjugated to a far-red emitting coumarin
}

\author{
Vojtech Novohradsky,${ }^{[\mathrm{a}]}$ Anna Rovira,${ }^{[\mathrm{b}]}$ Cormac Hally,${ }^{[\mathrm{c}]}$ Alex Galindo, ${ }^{[\mathrm{b}]}$ Gloria Vigueras, ${ }^{[\mathrm{d}]}$ Albert \\ Gandioso, ${ }^{[\mathrm{b}]}$ Marie Svitelova, ${ }^{[\mathrm{a}]}$ Roger Bresolí-Obach, ${ }^{[\mathrm{c}]}$ Hana Kostrhunova, ${ }^{[\mathrm{a}]}$ Lenka Markova, ${ }^{[\mathrm{a}]}$ Jana \\ Kasparkova, ${ }^{[a]}$ Santi Nonell, ${ }^{[c]}$ José Ruiz, ${ }^{*[\mathrm{~d}]}$ Viktor Brabec, ${ }^{*[a]}$ and Vicente Marchán ${ }^{\star[b]}$
}

\begin{abstract}
Although cyclometalated Ir(III) complexes have emerged as promising photosensitizers for photodynamic therapy, some key drawbacks still hamper clinical translation such as operability in the phototherapeutic window and ROS production efficiency and selectivity. In this work, we report a cyclometalated $\operatorname{Ir}($ III) complex conjugated to a far-red emitting coumarin with highly favourable properties for cancer phototherapy. Ir(III)-COUPY was efficiently taken up by living HeLa cells and showed no dark cytotoxicity and impressive photocytotoxicity indexes after blue (161) and green (85) light irradiation, even under hypoxia. Importantly, a clear correlation between cell death and intracellular superoxide anion radicals' generation after visible light irradiation was demonstrated. By taking advantage of the rich photophysical properties of COUPY fluorophores and of the well-stablished anticancer activities of $\operatorname{Ir}(\mathrm{III})$ complexes, this strategy opens the door to novel fluorescent PDT agents with promising applications in theragnosis.
\end{abstract}

Cyclometalated iridium(III) complexes ${ }^{[1]}$ have gained attention as promising photosensitizers (PS) in photodynamic therapy $(P D T)^{[2]}$ since they can generate cytotoxic reactive oxygen species (ROS) under light irradiation. While direct energy transfer from the PS to the ground state of molecular oxygen in Type II PDT yields singlet oxygen $\left({ }^{1} \mathrm{O}_{2}\right)$, the photochemical pathway Type I is more complex and involves the production of several types of ROS. ${ }^{[1 c]}$ To date, very few $\operatorname{Ir}($ III)-based PS operate in the phototherapeutic window, which represents a serious drawback for clinical translation owing to the poor tissue penetration and toxicity of high energetic wavelengths which inevitably cause off target toxicity. However, the choice of the optimal wavelength range will depend on the tumor invasion depth since unnecessary deeper tissue penetration could also impair PDT potency and damage underlying healthy tissues. ${ }^{[2 \mathrm{e}]}$

[a] Dr. V. Novohradsky, M. Svitelova, Dr. H. Kostrhunova, Dr. L. Markova, Dr. J. Kasparkova, Prof. V. Brabec Institute of Biophysics, Czech Academy of Sciences v.v.i. Kralovopolska 135, 61265 Brno, Czech Republic E-mail: brabec@ibp.cz

[b] A. Rovira, A. Galindo, Dr. A. Gandioso, Dr. V. Marchán Departament de Química Inorgànica i Orgànica, Secció de Química Orgànica, IBUB

Universitat de Barcelona

Martí i Franquès 1-11, E-08028 Barcelona, Spain

E-mail: vmarchan@ub.edu

[c] C. Hally, Dr. R. Bresolí-Obach, Prof. S. Nonell Institut Químic de Sarrià, Universitat Ramon Llull Vía Augusta 390, E-08017 Barcelona, Spain

[d] G. Vigueras, Prof. J. Ruiz

Departamento de Química Inorgánica

Universidad de Murcia and Institute for Bio-Health Research of

Murcia (IMIB-Arrixaca)

Campus de Espinardo, E-30071 Murcia, Spain

E-mail: jruiz@um.es
Ideally, metal-based PS should also operate under hypoxia ${ }^{[3]}$ and exhibit strong photocytotoxicity (e.g., high photocytoxicity indexes). This might be a problematic issue in the case of cyclometalated $\operatorname{Ir}(\mathrm{III})$ complexes due to their inherent high dark cytotoxicity and strong dependence of photocytotoxicity with ${ }^{1} \mathrm{O}_{2}$ production..$^{[1,4]}$ To address these problems, research efforts have been dedicated over the last few years to the development of novel PDT agents by combining organic fluorophores and metal complexes, either by integrating the chromophore within the metal coordination sphere via $\pi$-conjugated linkers or by simply attaching them together through a non- $\pi$-conjugated linker. This strategy takes advantage of the rich photophysical properties of organic fluorophores and of the well-stablished anticancer activities of metal complexes. ${ }^{[1]}$ Examples of this approach include boron-dipyrromethene (BODIPY) fluorophores, ${ }^{[5]}$ being the conjugation to cyclometalated iridium(III) complexes particularly appealing. ${ }^{[6]}$ Conventional coumarins have also been conjugated to Ir(III) complexes, either to increase singlet oxygen quantum yield ${ }^{[7]}$ or to target mitochondria. ${ }^{[8]}$

Fluorophores based on small organic molecules have become essential daily tools in bioimaging applications, both in basic research and in diagnoses and therapy. ${ }^{[9]}$ Recently, we have described a novel class of far-red/NIR-emitting fluorophores, nicknamed COUPYs, in which the carbonyl group of conventional coumarin 1 (Scheme 1) was replaced with $\mathrm{N}$ alkylated cyano(4-pyridine)methylene moieties (e.g., compound 2 ) to increase the push-pull character of the aromatic system. ${ }^{[10]}$ Besides operating within the optical window of biological tissues, COUPY dyes exhibit several appealing features, such as brightness, high photostability and large Stokes' shifts. ${ }^{[10]}$

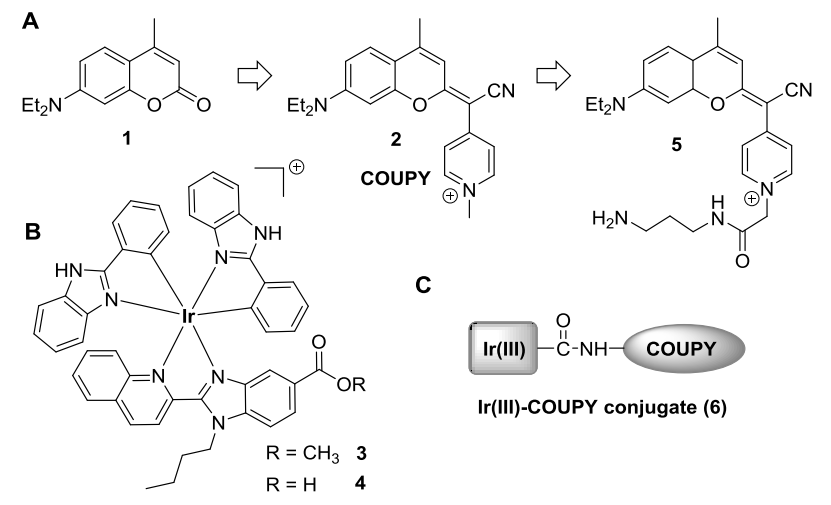

Scheme 1. (A) Rational design of COUPY fluorophores. (B) Structure of cyclometalated iridium(III) complexes. (C) Schematic representation of the $\operatorname{Ir}(I I I)$-COUPY conjugate described in this work. 
Based on these antecedents, we envisaged COUPY fluorophores as promising candidates for developing novel fluorescent-PDT agents in combination with highly potent cyclometalated $\operatorname{Ir}(\mathrm{III})$ anticancer complexes which contain a 2quinolinylbenzimidazole $\mathrm{N}^{\wedge} \mathrm{N}$ ligand (e.g., complex 3$) .{ }^{[11]}$ Herein, we report for the first time the synthesis and biological evaluation of a potential PS agent that combines a cyclometalated $\operatorname{Ir}($ III) complex with a representative COUPY dye (Scheme 1), and demonstrated a good correlation between cell death and superoxide anion radicals' production, which were selectively generated after visible light irradiation.

The attachment of the $\operatorname{Ir}(\mathrm{III})$ complex to the fluorophore was carried out through the formation of an amide bond between the carboxylic acid function of $\mathbf{4}$ and the free amino group of coumarin 5 (see Scheme 1 and the Supporting Information for further details). The expected Ir(III)-COUPY conjugate (6) was obtained as a dark purple solid after purification by silica column chromatography, and fully characterized by HR ESI-MS and ${ }^{1} \mathrm{H}$ and ${ }^{13} \mathrm{C}$ NMR. Conjugate 6 was found completely soluble in water, which represents an important improvement with respect the metal complex, and stable in cell culture medium (DMEM supplemented with $10 \%$ FBS) (Figure S2).

The photophysical properties of conjugate 6 were studied in four solvents of different polarity and compared with those of coumarin 2 and $\operatorname{Ir}(\mathrm{III})$ complex 3 (Table S1 and Figures 1 and S3-S9). The most relevant findings are that the $\operatorname{Ir}(\mathrm{III})$ complex shows strong red phosphorescence $(660 \mathrm{~nm})$, whose intensity decreases in the conjugate in a solvent dependent manner, indicating that competitive excited-state processes take place. Regarding the coumarin, it shows strong fluorescence (599-609 $\mathrm{nm}$ ), whose intensity and lifetime decreases strongly in the conjugate, indicating again the existence of competitive excitedstate processes. Fluorescence of the coumarin can also be observed when the $\operatorname{Ir}(\mathrm{III})$ complex is selectively photoexcited in the conjugate, indicating fast energy transfer from the $\operatorname{Ir}(\mathrm{III})$ complex to the coumarin moiety. In the presence of oxygen, the Ir(III) complex produces singlet oxygen $\left({ }^{1} \mathrm{O}_{2}\right)$ in all organic solvents but not in PBS. The coumarin is a much worse photosensitizer in all solvents, however its ${ }^{1} \mathrm{O}_{2}$ quantum yield increases by one order of magnitude in the conjugate, indicating an enhanced intersystem crossing induced by the heavy $\operatorname{Ir}(\mathrm{III})$ ion, which is consistent with the shortening of its fluorescence lifetime. Nevertheless, no singlet oxygen can be observed in PBS. Very similar quantum yields are observed when either the Ir(III) complex or the coumarin moiety are selectively photoexcited in organic solvents in conjugate $\mathbf{6}$, indicating almost $100 \%$ efficient singlet-singlet energy transfer from the Ir(III) complex to the coumarin. In PBS no ${ }^{1} \mathrm{O}_{2}$ was observed at either excitation wavelength for any of the compounds.

Besides operability in the phototherapeutic window, good photostability is desirable in a PS to allow visualization of the tumour for a sufficiently long period. We then evaluated the photostability of $\mathbf{6}$ under green light irradiation and compared it with that of three control compounds, the parent coumarin 2, Rose Bengal (RB) and meso-tetra(4-sulfonatophenyl)porphyrin (TPPS). As shown in Figure 1, conjugate 6 was slightly more resistant to photobleaching than $\mathrm{RB}$, which is a commonly used
PS for studies in biological systems. As expected, TPPS was the highest photostable compound. Nevertheless, it is worth noting that conjugate 6 was found photostable up to light fluences larger than those typically used for cell imaging purposes. ${ }^{[10 a]}$
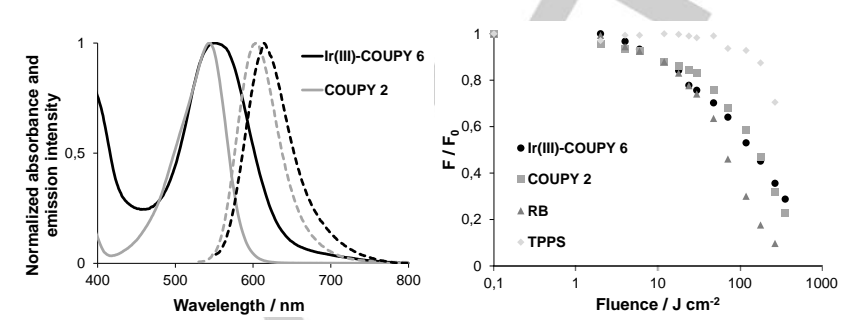

Figure 1. Left: Comparison of the normalized absorption (solid lines) and fluorescence emission (dotted lines) spectra of the compounds in PBS buffer Right: Fluorescence bleaching of the compounds irradiated with green light.

The cellular uptake of conjugate 6 was studied in living HeLa cells by confocal microscopy by irradiation with a yellow light laser $\left(\lambda_{\text {ex }}=561 \mathrm{~nm}\right)$. As shown in Figure 2, 6 was efficiently taken up by the cells since fluorescent vesicles were clearly observed in the cytoplasm of all the examined cells. By contrast, coumarin 2 accumulates preferentially in mitochondria and nucleoli. ${ }^{[10 a]}$ To further investigate the cellular uptake of the conjugate, Ir accumulation was quantitatively determined by ICP-MS after incubation of HeLa cells with iridium compounds. As shown in Table 1 , the accumulation of 6 at $37^{\circ} \mathrm{C}$ was slightly higher (about 1.6-fold) than that of the parent complex (3), which indicates that conjugation to the coumarin has a positive effect both on internalization and accumulation. Very interestingly, the accumulation of conjugate 6 was not modified when incubation was carried out at $4{ }^{\circ} \mathrm{C}$. By contrast, the amount of cellular Ir accumulation was considerably reduced after incubation with 3 at low temperature, which points to an energy-dependent pathway. The overall cellular uptake experiments indicate that the internalization pathway of $\operatorname{Ir}($ III)-COUPY conjugate differs from that of the two separated moieties since it does not accumulate in specific organelles such as mitochondria or nucleoli but in the cytoplasm, and enters the cells through an energy-independent uptake mechanism.

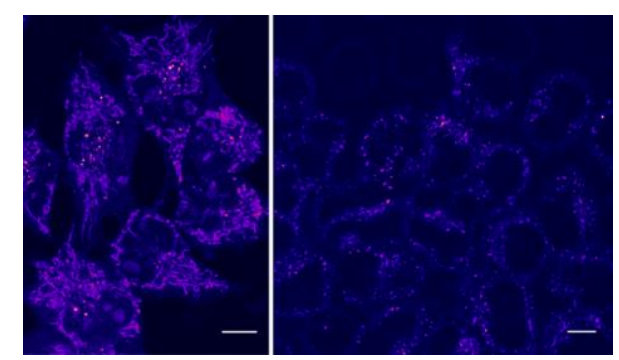

Figure 2. Comparison of the cellular uptake of $\operatorname{Ir}(\mathrm{III})$-COUPY conjugate $\mathbf{6}$ and coumarin 2. Single confocal planes of HeLa cells incubated with 2 (left) and 6 (right) for $30 \mathrm{~min}$ at $37^{\circ} \mathrm{C}$. Scale bar: $10 \mu \mathrm{m}$. 
Table 1. Cellular Ir accumulation determined by means of ICP-MS in HeLa cells at $4^{\circ} \mathrm{C}$ and $37^{\circ} \mathrm{C} .^{[a]}$

\begin{tabular}{ccccc}
\hline & \multicolumn{2}{c}{$\mathrm{ng}$ Ir $/ 10^{6}$ cells } & \multicolumn{2}{c}{ pmol Ir $/ 10^{6}$ cells } \\
& $4^{\circ} \mathrm{C}$ & \multicolumn{1}{c}{$37^{\circ} \mathrm{C}$} & $4^{\circ} \mathrm{C}$ & $37^{\circ} \mathrm{C}$ \\
\hline $\operatorname{Ir}($ III) complex 3 & $1.3 \pm 0.2$ & $7.6 \pm 0.4$ & $6.5 \pm 1.0$ & $39.4 \pm 2.2$ \\
$\operatorname{Ir}($ III)-COUPY 6 & $11.6 \pm 1.0$ & $12.1 \pm 0.7$ & $60.4 \pm 5.2$ & $62.8 \pm 3.4$ \\
\hline
\end{tabular}

[a] HeLa cells were incubated for $2 \mathrm{~h}$ with $5 \mu \mathrm{M}$ of $\mathrm{Ir}$ compounds at $4{ }^{\circ} \mathrm{C}$ or $37^{\circ} \mathrm{C}$. Results are the mean $\pm S D$ s from three independent experiments.

The in vitro antitumor activity of 6 was tested in HeLa cells first in normoxic conditions $\left(21 \% \mathrm{O}_{2}\right)$. Photocytotoxicity was also assessed via irradiation with visible light, either with a dose of 28 $\mathrm{J} \mathrm{cm}^{-2}$ of blue light or with $21 \mathrm{~J} \mathrm{~cm}^{-2}$ of green light. Such doses of blue and green light are typically used in photocytotoxicity studies with metallodrugs. ${ }^{[13]}$ The parent compounds (coumarin 2 and complex 3 ) were also tested to investigate the effect of conjugation. In both cases, the MTT assay was performed after $72 \mathrm{~h}$ of incubation. As shown in Table 2, conjugation between the $\operatorname{Ir}$ (III) complex and the fluorophore led to a negative effect on cytotoxicity since the resulting conjugate was found much less cytotoxic. This result is particularly surprising considering the higher accumulation of the conjugate compared with the parent complex (Table 1). To our delight, visible light irradiation clearly improved the antitumor activity of the conjugate, leading to $\mathrm{IC}_{50}$ values of 2.51 (green) and 1.32 (blue) $\mu \mathrm{M}$. Furthermore, the low dark cytotoxicity of conjugate 6 led to excellent PI values both after green (85) and blue (161) light irradiation. The PI of 6 after irradiation with biologically-compatible green light is particularly impressive when compared with that of complex 3 (85 vs 2.9, respectively). Although not investigated in this work, yellow and even red light could be used to activate conjugate 6 by taking advantage of the absorption spectrum of the coumarin moiety. The high photocytotoxicity of coumarin 2 suggests a disruption of the mitochondrial function given its preferred accumulation in this organelle. ${ }^{[10 a]}$

Having confirmed a close relationship between visible light irradiation and cytotoxicity, we investigated ROS generation inside the cells, either in the dark or after irradiation. Although the three compounds generate a basal level of intracellular ROS in the dark (Figures 3 and S6), a remarkable increase in ROS production occurred in the case of conjugate 6 after visible light irradiation when compared with parent compounds $\mathbf{2}$ and $\mathbf{3}$, specially with blue light, which cannot be exclusively attributed to a higher accumulation (see ROS quantification of 3 and 6 normalized to the level of cellular Ir accumulation in Figure 3). Overall, these results show a clear correlation between the photocytotoxicity of the $\operatorname{Ir}(\mathrm{III})$-COUPY conjugate and intracellular ROS generation, which confirms its potential applications as PS since the production of ROS is the main mechanism for PDTinitiated cell death. In order to get more insights into the photocytotoxicity of the conjugate, the antiproliferative activity of all the compounds was tested under low-oxygen conditions (2\% $\mathrm{O}_{2}$ ). Very interestingly, the cytotoxicity of the compounds was similar in both, normoxic and hypoxic conditions (Table 2), which makes Ir(III)-COUPY conjugates greatly ideal candidates for the treatment of hypoxic tumours.

Table 2. Cytotoxicity of the compounds towards HeLa cells. ${ }^{[\mathrm{a}]}$

\begin{tabular}{|c|c|c|c|c|c|c|}
\hline & & $\begin{array}{l}\text { Dark } \\
\mathrm{IC}_{50}(\mu \mathrm{M})\end{array}$ & $\begin{array}{l}\text { Green } \\
\mathrm{IC}_{50}(\mu \mathrm{M})\end{array}$ & $\mathrm{Pl}^{[\mathrm{b}]}$ & $\begin{array}{l}\text { Blue } \\
\mathrm{IC}_{50}(\mu \mathrm{M})\end{array}$ & $\mathrm{PI}^{[\mathrm{b}]}$ \\
\hline 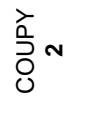 & $\begin{array}{l}\text { Normox } \\
\text { Hypox }\end{array}$ & $\begin{array}{l}38.7 \pm 4.1 \\
46.3 \pm 3.1\end{array}$ & $\begin{array}{l}0.34 \pm 0.11 \\
0.46 \pm 0.08\end{array}$ & $\begin{array}{r}114 \\
101\end{array}$ & $\begin{array}{l}0.37 \pm 0.09 \\
0.44 \pm 0.13\end{array}$ & $\begin{array}{l}105 \\
105\end{array}$ \\
\hline 竧 욜 & $\begin{array}{l}\text { Normox } \\
\text { Hypox }\end{array}$ & $\begin{array}{l}95.2 \pm 6.4 \\
101 \pm 10\end{array}$ & $\begin{array}{l}32.7 \pm 4.9 \\
31.5 \pm 3.3\end{array}$ & $\begin{array}{l}2.9 \\
3.2\end{array}$ & $\begin{array}{l}2.02 \pm 0.24 \\
2.52 \pm 0.19\end{array}$ & $\begin{array}{l}47 \\
40\end{array}$ \\
\hline 产亥 & $\begin{array}{l}\text { Normox } \\
\text { Hypox }\end{array}$ & $\begin{array}{l}213 \pm 14 \\
219 \pm 6\end{array}$ & $\begin{array}{l}2.51 \pm 0.32 \\
2.77 \pm 0.20\end{array}$ & $\begin{array}{l}85 \\
79\end{array}$ & $\begin{array}{l}1.32 \pm 0.09 \\
1.43 \pm 0.11\end{array}$ & $\begin{array}{l}161 \\
153\end{array}$ \\
\hline
\end{tabular}

[a] Cells were treated for $2 \mathrm{~h}$ ( $1 \mathrm{~h}$ of incubation, $1 \mathrm{~h}$ of irradiation at doses of 28 $\mathrm{J} \mathrm{cm}^{-2}$ of blue or $21 \mathrm{~J} \mathrm{~cm}^{-2}$ of green light) followed by $70 \mathrm{~h}$ of incubation in drug-free medium. Control cells were left in the dark. Cells were cultured under normoxia $\left(21 \% \mathrm{O}_{2}\right)$ and hypoxia $\left(2 \% \mathrm{O}_{2}\right)$. Results are the means \pm SDs from three independent experiments. [b] PI - Phototoxicity index was calculated by the following formula: PI (Blue, Green) $=\mathrm{IC}_{50}$ (dark-nonirradiated cells) / IC 50 (irradiated cells; blue, green).

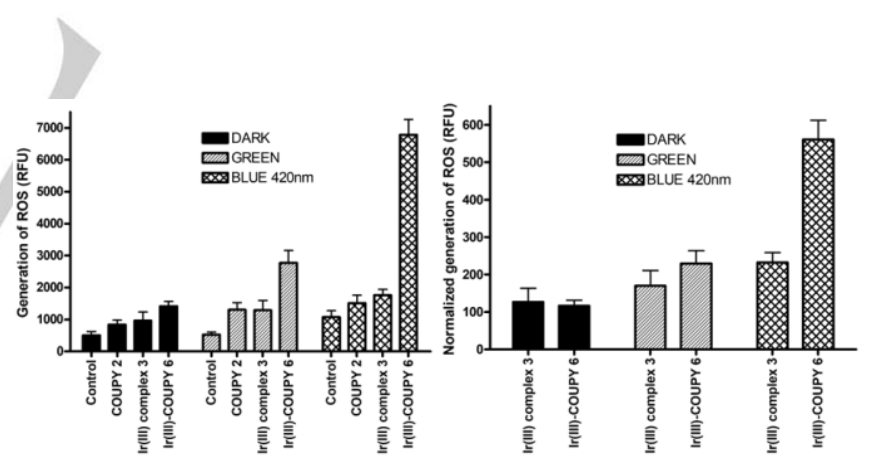

Figure 3. Left: Quantification of ROS determined by flow cytometry in HeLa cells. Cells were treated with $10 \mu \mathrm{M}$ of the compounds for $1 \mathrm{~h}$ in the dark followed by $1 \mathrm{~h}$ of irradiation with green $\left(21 \mathrm{~J} \mathrm{~cm}^{-2}\right)$ or blue light $\left(28 \mathrm{~J} \mathrm{~cm}^{-2}\right)$. Right: Quantification of ROS normalized to the level of cellular uptake (ng $\mathrm{Ir} / 10^{6}$ cells) of $\mathrm{Ir}$ compounds determined at $37^{\circ} \mathrm{C}$. Bars represent the mean relative fluorescence intensities coming from CellRox ${ }^{\circledR}$ reagent. Error bars were calculated from three independent experiments.

We then focused on identifying the specific cytotoxic ROS involved in cell death. Although cyclometalated $\operatorname{Ir}(\mathrm{III})$ complexes typically produce ${ }^{1} \mathrm{O}_{2},{ }^{[1]}$ many other cytotoxic ROS can also be generated through type I photochemical processes such as hydrogen peroxide $\left(\mathrm{H}_{2} \mathrm{O}_{2}\right)$, hydroxyl radicals $\left({ }^{\circ} \mathrm{OH}\right)$, superoxide anion radicals $\left({ }^{\circ} \mathrm{O}_{2}^{-}\right)$, peroxynitrite anion $\left(\mathrm{ONOO}^{-}\right)$, etc. ${ }^{[14]}$ To determine the specific ROS generated after treatment with $\operatorname{Ir}(\mathrm{III})$ - 
COUPY conjugate 6, HeLa cells were previously treated with several selective ROS scavengers, including sodium pyruvate $\left(\mathrm{H}_{2} \mathrm{O}_{2}\right)$, D-mannitol $\left({ }^{\circ} \mathrm{OH}\right)$, tiron $\left({ }^{\circ} \mathrm{O}_{2}{ }^{-}\right)$, sodium azide $\left({ }^{1} \mathrm{O}_{2}\right)$ and ebselen (ONOO-). As shown in Figures 4 and $\mathrm{S} 11$, only the use of tiron was able to prevent the intracellular production of ROS, which suggested the generation of superoxide anion radicals in the cells after visible (blue or green) light irradiation in the presence of $\operatorname{Ir}(\mathrm{III})$-COUPY conjugate 6. Very interestingly, scavenging studies ruled out the production of other types of ROS from conjugate 6 , including that of ${ }^{1} \mathrm{O}_{2}$, which agrees with the photophysical studies in PBS. In contrast, neither of the two components separately, COUPY 2 and $\operatorname{Ir}(\mathrm{III})$ complex $\mathbf{3}$, led to a significant production of ROS in $\mathrm{HeLa}$ cells, including ${ }^{\circ} \mathrm{O}_{2}{ }^{-}$ (Figures S12-S15).

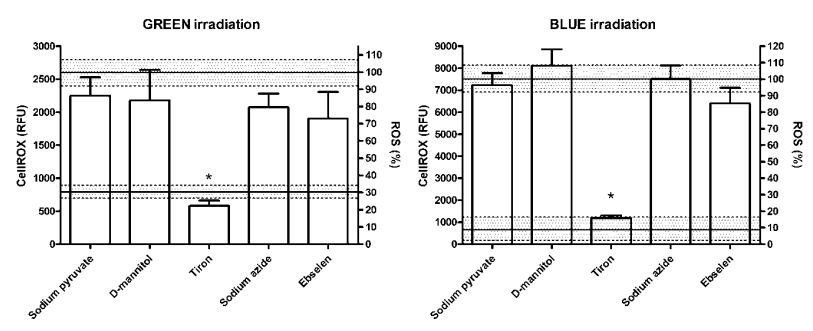

Figure 4. Data analysis for determination of ROS in Hela cells by the flow cytometry after the irradiation with green (left) of blue light (right). Cells were pre-incubated with specific ROS scavengers and then treated with 6 ( $1 \mathrm{~h}$ in the dark followed by $1 \mathrm{~h}$ under the irradiation).

Further confirmation of the generation of superoxide anion radical from conjugate 6 was obtained by using a cell-based assay for the measurement of ${ }^{\circ} \mathrm{O}_{2}^{-}$status in whole cells. ${ }^{[15]}$ As shown in Figure S16, a significant increase of the luminescence signal with irradiation time of HeLa cells pre-treated with 6 was observed, indicating oxidation of luminol substrate. The oxidation of luminol was likely due to the generation of superoxide anion radical, as suggests the reduction of the signal in the presence of superoxide dismutase (SOD), an enzyme that catalyzes ${ }^{\circ} \mathrm{O}_{2}^{-}$disproportionation reactions to form $\mathrm{H}_{2} \mathrm{O}_{2}$ and $\mathrm{O}_{2} \cdot{ }^{[16]}$ In addition, the use of dihydrorhodamine 123 (DHR123), a non-fluorescent probe that emits green fluorescence after reaction with $\mathrm{O}_{2}^{-}$, allowed to confirm the generation of superoxide anion radical in cell-free media. ${ }^{[16]}$ As shown in Figure S17, conjugate 6 increased fluorescence intensity of DHR123 markedly more than the $\operatorname{Ir}($ III) complex $\mathbf{3}$ and COUPY 2 Moreover, that increase was significantly suppressed in the presence of SOD and ascorbate (Figure S18), thereby confirming the involvement of ${ }^{\circ} \mathrm{O}_{2}^{-}$in oxidation processes leading to the fluorescence signal. Interestingly, SOD did not show any effect in the case of COUPY 2 , in contrast to nonspecific reductant sodium ascorbate, which suggests that processes other than ${ }^{\circ} \mathrm{O}_{2}^{-}$production might be responsible for the photo effects of 2. Furthermore, laser flash photolysis experiments revealed the production of different transient species (Figure S9). Thus, at $570 \mathrm{~nm}$ the decay was dominated by the lifetime of the coumarin triplet state ( 3.8 and $0.6 \mu \mathrm{s}$ in the absence and presence of oxygen). At $630 \mathrm{~nm}$ a longer lived transient was observed, whose lifetime decreased strongly in the presence of oxygen. We interpret this as a reduced form of the $\operatorname{Ir}(\mathrm{III})$ complex that is scavenged by oxygen to produce ${ }^{\circ} \mathrm{O}_{2}{ }^{-}$. Finally, a third species was observed at $490 \mathrm{~nm}$, whose lifetime increased in the presence of oxygen. This is interpreted as the cation radical of the coumarin moiety ${ }^{[17]}$ since reoxidation of the reduced form of the $\operatorname{Ir}(\mathrm{III})$ complex by oxygen prevents intramolecular charge recombination. Nevertheless, a complete unravelling of the photochemical behaviour of $\operatorname{Ir}($ III)-COUPY conjugates requires further experiments and will be published elsewhere. To the best of our knowledge, this is the first example of selective production of superoxide anion radical from a compound based on a cyclometalated $\operatorname{Ir}(\mathrm{III})$ complex after visible light irradiation in cells. ${ }^{[18]}$ Hence, the covalent attachment of the coumarin-based COUPY fluorophore to the metal complex not only improves cellular uptake and photocytotoxicity under visible light irradiation but also triggers the production of highly cytotoxic ${ }^{\circ} \mathrm{O}_{2}{ }^{-}$.

Finally, to investigate the involvement of superoxide anion radicals in cell death, we determined the viability of HeLa cells after treatment with conjugate $\mathbf{6}$ under the irradiating conditions, both in the absence and in the presence of tiron. As shown in Figure S19, the photocytotoxicity of $\mathbf{6}$ was completely abolished in the cells pre-treated with the ROS scavenger, which confirms the active role of ${ }^{\circ} \mathrm{O}_{2}^{-}$in cell death. Excessive ${ }^{\circ} \mathrm{O}_{2}^{-}$, which is one of the most toxic ROS, is known to irreversibly damage cellular components by reacting with proteins, DNA and lipids. ${ }^{[19]}$ Moreover, disproportionation reactions involving ${ }^{\circ} \mathrm{O}_{2}^{-}$might trigger the formation of other highly toxic ROS.

In summary, we have reported the first example of a novel PS agent based on the conjugation of a cyclometalated $\operatorname{Ir}(\mathrm{III})$ complex to a coumarin-based COUPY fluorophore. $\operatorname{Ir}(\mathrm{III})$ COUPY conjugate (6) exhibits several interesting features for cancer phototherapy such as aqueous solubility, excellent cellular uptake and high photocytotoxicity under visible light irradiation, both in normoxia and hypoxia, being the PI values after blue and green light irradiation particularly appealing owing to its low dark cytotoxicity compared with the parent compounds, especially with the coumarin. Very importantly, treatment with 6 generates a specific type I ROS in living cells upon visible light irradiation, superoxide anion radicals $\left({ }^{\circ} \mathrm{O}_{2}^{-}\right)$, whose production has been further confirmed through spectroscopic methods and correlated with cell death according to cellular viability experiments with tiron scavenger. Moreover, HeLa cells could be visualized by confocal microscopy by using a yellow light laser owing to the spectroscopic properties of the organic fluorophore in $\operatorname{Ir}(\mathrm{III})$-COUPY conjugate. Overall, these properties indicate that conjugation between far-red/NIR-emitting COUPY coumarins and highly potent cyclometalated Ir(III) complexes can be exploited to overcome some of the drawbacks of traditional PS such as poor tissue penetration and $\mathrm{O}_{2}$-tension dependency, ${ }^{[16,20]}$ leading to fluorescent-PDT agents with promising applications in diagnosis and photodynamic therapy against hypoxic tumours. Work is in progress in our laboratory to develop novel $\operatorname{Ir}(\mathrm{III})$-fluorophore conjugates operating in the phototherapeutic window, especially in the far-red and NIR region, with the aim of using them in targeted PDT. 


\section{Acknowledgements}

This work was supported by funds from the Spanish Ministerio de Economía y Competitividad and FEDER funds (grants CTQ2014-52658-R, CTQ2015-64319-R, CTQ2016-78454-C2-1$\mathrm{R}$ and CTQ2017-84779-R) and the Generalitat de Catalunya (2017 DI 072). The authors acknowledge helpful assistance of Dr. Francisco Cárdenas (NMR), Dr. Manel Bosch (Confocal Microscopy) and Dr. Irene Fernández and Laura Ortiz (MS) from CCiTUB. A.G. was a recipient fellow of the University of Barcelona. G.V. thanks the University of Murcia for a grant (R1034/2016). C.H. thanks the European Social Funds and the SUR of DEC of the Generalitat de Catalunya for his predoctoral fellowships (Grants No. 2017 FI_B 00617, 2018 FI_B1 00174 and 2019 FI_B2 00167). VN, MS and VB acknowledge the support from the Czech Science Foundation, Grant No. 1809502S.

Keywords: Coumarin • Cyclometalated iridium(III) complexes • Conjugation $\cdot$ Photodynamic therapy $\bullet$ Photosensitizer

[1] a) Z. Liu, P. J. Sadler, Acc. Chem. Res. 2014, 47, 1174-1185; b) C. C. Konkankit, S. C. Marker, K. M. Knopf, J. J. Wilson, Dalton Trans. 2018 47, 9934-9974; c) A. Zamora, G. Vigueras, V. Rodríguez, M. D. Santana, J. Ruiz, Coord. Chem. Rev. 2018, 360, 34-76.

[2] a) D. E. Dolmans, D. Fukumura, R. K. Jain, Nat. Rev. Cancer. 2003, 3, 380-387; b) F. Heinemann, J. Karges, G. Gasser, Acc. Chem. Res. 2017, 50, 2727-2736; c) X. Li, S. Lee, J. Yoon, Chem. Soc. Rev. 2018 47, 1174-1188; d) B. M. Luby, C. D. Walsh, G. Zheng, Angew. Chem. Int. Ed. 2018, 57, 2-14; e) S. Monro, K. L. Colón, H. Yin, J. Roque, P. Konda, S. Gujar, R. P. Thummel, L. Lilge, C. G. Cameron, S. A. McFarland, Chem. Rev. 2019, 119, 797-828.

[3] X. Li, N. Kwon, T. Guo, Z. Liu, J. Yoon, Angew. Chem. Int. Ed. 2018, 57 11522-11531.

[4] a) K. V. Sudheesh, P. S. Jayaram, A. Samanta, K. S. Bejoymohandas, R. S. Jayasree, A. Ajayaghosh, Chem. Eur. J. 2018, 24, 10999-11007 b) P. Zhang, H. Huang, S. Banerjee, G. J. Clarkson, C. Ge, C. Imberti, P. J. Sadler, Angew. Chem. Int. Ed. 2019, 58, 2350-2354.

[5] B. Bertrand, K. Passador, C. Goze, F. Denat, E. Bodio, M. Salmain, Coord. Chem. Rev. 2018, 358, 108-124.

[6] a) E. Palao, R. Sola-Llano, A. Tabero, H. Manzano, A. R. Agarrabeitia, A. Villanueva, I. López-Arbeloa, V. Martínez-Martínez, M. J. Ortiz, Chem. Eur. J. 2017, 23, 10139-10147; b) L. Tabrizi, H. Chiniforoshan RSC Adv. 2017, 7, 34160-34169. c) P. Majumdar, X. Yuan, S. Li, B. L.
Guennic, J. Ma, C. Zhang, D. Jacquemin, J. Zhao, J. Mater. Chem. B 2014, 2, 2838-2854.

[7] Y. Lu, R. Conway-Kenny, J. Wang, X. Cui, J. Zhao, S. M. Draper, Dalton Trans. 2018, 47, 8585-8589

[8] R.-R. Ye, C.-P. Tan, L.-N. Ji, Z.-W. Mao, Dalton Trans. 2016, 45, 13042-13051.

[9] a) M. Srinivasarao, C. V. Galliford, P. S. Low, Nat. Rev. Drug Discovery 2015, 14, 203-219; b) R. R. Zhang, A. B. Schroeder, J. J. Grudzinski, E. L. Rosenthal, J. M. Warram, A. N. Pinchuk, K. W. Eliceiri, J. S. Kuo, J. P. Weichert, Nat. Rev. Clin. Oncol. 2017, 14, 347-364; c) M. Gao, F. Yu, C. Lv, J. Choo, L. Chen, Chem. Soc. Rev. 2017, 46, 2237-2271.

[10] a) A. Gandioso, R. Bresolí-Obach, A. Nin-Hill, M. Bosch, M. Palau, A Galindo, S. Contreras, A. Rovira, C. Rovira, S. Nonell, V. Marchán, J. Org. Chem. 2018, 83, 1185-1195; b) A. Gandioso, M. Palau, R. BresolíObach, A. Galindo, A. Rovira, M. Bosch, S. Nonell, V. Marchán, J. Org. Chem. 2018, 83, 11519-11531; c) A. Rovira, A. Gandioso, M. Goñalons, A. Galindo, A. Massaguer, M. Bosch, V. Marchán, J. Org. Chem. 2019, 84, 1808-1817.

[11] a) J. Yellol, S. A. Pérez, G. Yellol, J. Zajac, A. Donaire, G. Vigueras, V. Novohradsky, C. Janiak, V. Brabec, J. Ruiz, Chem. Commun. 2016, 52, 14165-14168. b) V. Novohradsky, A. Zamora, A. Gandioso, V. Brabec, J. Ruiz, V. Marchán, Chem. Commun. 2017, 53, 5523-5526.

[12] a) Ti. Huang, Q. Yu, S. Liu, K. Yin Zhang, W. Huang, Q. Zhao, ChemBioChem 2018, 19, 1-12; b) J. Pracharova, G. Vigueras, V. Novohradsky, N. Cutillas, C. Janiak, H. Kostrhunova, J. Kasparkova, J. Ruiz, V. Brabec, Chem. Eur. J. 2018, 24, 4607-4619.

[13] a) S. L. Hopkins, B. Siewert, S. H. C. Askes, P. Veldhuizen, R. Zwier Michal Heger, S. Bonnet, Photochem. Photobiol. Sci. 2016, 15, 644 653 ; b) V. H. S. van Rixel, B. Siewert, S. L. Hopkins, S. H. C. Askes, A Busemann, M. A. Siegler, S. Bonnet, Chem. Sci. 2016, 7, 4922-4929.

[14] T. P. Devasagayam, J. C. Tilak, K. K. Boloor, K. S. Sane, S. S Ghaskadbi, R. D. Lele, J. Assoc. Physicians India 2004, 52, 794-804.

[15] D. Mihov, J. Vogel, M. Gassmann, A. Bogdanova, Am. J. Physiol. Cell Physiol. 2009, 297: C378-C388.

[16] M. Li, J. Xia, R. Tian, J. Wang, J. Fan, J. Du, S. Long, X. Song, J. W. Foley, X. J. Peng, J. Am. Chem. Soc. 2018, 140, 14851-14859.

[17] A. Aspée, E. Alarcon, E. Pino, S. I. Gorelsky, J. C. Scaiano, J. Phys. Chem. A, 2012, 116, 199-206.

[18] a) L. He, K.-N. Wang, Y. Zheng, J.-J. Cao, M.-F. Zhang, C.-P. Tan, L.-N. Ji, Z.-W. Mao. Dalton Trans. 2018, 47, 6942-6953; b) J.-S. Nam, M.-G Kang, J. Kang, S.-Y. Park, S. J. C. Lee, H.-T. Kim, J. K. Seo, O.-H. Kwon, M. H. Lim, H.-W. Rhee, T.-H. Kwon, J. Am. Chem. Soc. 2016, 138, 10968-10977.

[19] G.-Y. Liou, P. Storz, Free Radicals Res. 2010, 44, 479-496.

[20] H. Abrahamse, M. R. Hamblin, Biochem. J. 2016, 473, 347-364. 
Entry for the Table of Contents (Please choose one layout)

\section{COMMUNICATION}

We report a cyclometalated Ir(III) complex conjugated to a far-red emitting coumarin fluorophore that selectively generates superoxide anion radicals in living cells after irradiation with visible light, and demonstrate a clear correlation between the production of type I ROS and cell death. This compound represents the first example of a novel class of fluorescent-PDT agents with potential applications in cancer phototherapy and diagnosis.

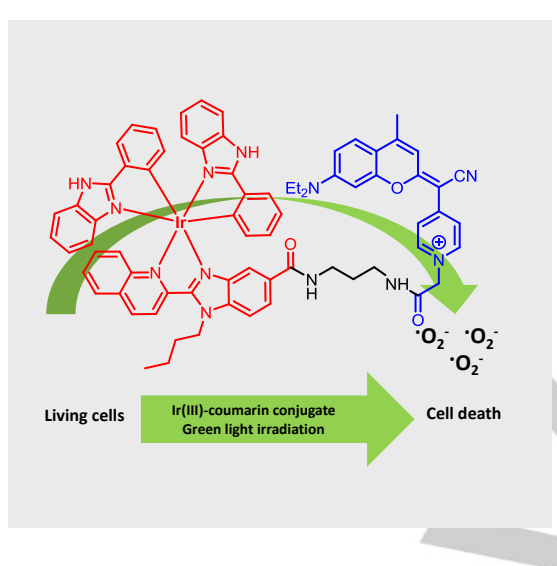

Vojtech Novohradsky, Anna Rovira, Cormac Hally, Alex Galindo, Gloria Vigueras, Albert Gandioso, Marie Svitelova, Roger Bresolí-Obach, Hana Kostrhunova, Lenka Markova, Jana Kasparkova, Santi Nonell, José Ruiz, * Viktor Brabec* and Vicente Marchán*

Page No. - Page No.

Towards novel photodynamic anticancer agents generating superoxide anion radicals: $\mathbf{A}$ cyclometalated Ir(III) complex 